\title{
Conversion of Palm Oil to Biodiesel Using TiO2/Monmorillorite (MMT) Composite Catalyst from Aceh Tamiang Bentonite
}

\author{
Ida Ratna Nila, Nirmala Sari, Rachmad Almi Putra, Rahmawati, Teuku Andi Fadlly* \\ Department of Physics \\ Universitas Samudra \\ Langsa, Indonesia \\ *andifadly@unsam.ac.id
}

\begin{abstract}
The main objective of this research is to produce TiO2/Monmorillorite (MMT) composites as a biodiesel catalyst characterized using X-ray diffraction (XRD). In addition, to see the percentage of biodiesel production, it will be characterized using Chromatography Mass Spectrometry (GC-MS). TiO2/MMT composites are used as a catalyst for the production of biodiesel from palm oil. The composite sample was prepared with using the solid state method and it was enough to mix $\mathrm{TiO2}$ and MMT powder with a ratio of $25: 75 \mathrm{wt} \%$. In the biodiesel production process, the authors use the transesterification method, where the ratio between methanol and palm oil with a molar ratio of 12: 1 and TiO2/MMT composites catalyst is 3 grams. The transesterification process was carried out at a reaction temperature of $60^{\circ} \mathrm{C}$ for 3 hours. The results showed that the TiO2/MMT composites catalyst did not experience acid activation to produce biodiesel from palm oil. Fatty Acid Methyl Ester (FAME) produced in this process is $60.89 \%$.
\end{abstract}

Keywords—biodiesel, TiO2, monmorillorite, composite, bentonite

\section{INTRODUCTION}

Biodiesel is a biofuel that can be used to substitute fossil fuels, especially diesel oil. It also tackles environmental issues such as carbon monoxide and sulfur emission reduction [1]. Solar energy use can be improved by using biodiesel. Biodiesel can help to minimize the use of diesel oil. Entermorpha intestinalis, which is extracted for biodiesel production using zinc-based iron oxide nanocomposites as a catalyst [2], is one example of animal fats and microorganisms that can generate biodiesel [3]. $\mathrm{CaO}$ nanocatalysts are used to convert microalgae into biodiesel [4]. Furthermore, biodiesel can be made from vegetable oil, as demonstrated in previous studies, such as biodiesel made from flaxseed oil using a $\mathrm{KOH}$ catalyst [5]. Biodiesel production from soybean oil using a wellcharacterized active solid acid catalyst $\left(\mathrm{SO}_{4}{ }^{2-} \mathrm{ZnO}\right.$ dan $\mathrm{SO}_{4}^{2} / \mathrm{ZnO}$ ) [6]. In addition, using $\mathrm{ZnO}$ in bentonite, a biodiesel conversion of $88 \%$ of soybean oil was achieved [7]. Monmorillorite (MMT) has also been synthesized from bentonite for the purification of patchouli oil [8]. Bentonite is a local potential as a catalyst material in the study of biodiesel conversion from vegetable oils, such as palm oil, in Aceh Tamiang, Aceh, Indonesia. Indonesia is an agricultural country that produces the most palm oil in the world [9]. This, particularly biodiesel, can be used as a renewable energy source. Apart from palm oil, sludge palm oil also produces biodiesel through enzymatic esterification with immobilized lipase as a biocatalyst [10], with an alum catalyst for esterification and a $\mathrm{KOH}$ catalyst for transesterification [11].

Aside from $\mathrm{ZnO}$, which is a metal oxide, $\mathrm{TiO} 2$ is a photocatalyst material. As a catalyst, TiO2/MMT composites were used, with MMT derived from the synthesis of bentonite in Aceh Tamiang, Aceh, Indonesia. This hasn't been looked at in terms of the transesterification process for making biodiesel from palm oil, so it'll be interesting to look into. With this context in mind, this research aims to generate a percentage of biodiesel from palm oil using a TiO2/MMT composite from Aceh Tamiang bentonite in Indonesia.

\section{METHODS}

Experiments in Aceh Tamiang, Indonesia, using MMT powder purified from natural bentonite [8]. By combining MMT powder with $\mathrm{TiO}_{2}$ (Emsure), the solid-state approach is used to render composite samples [12]. The weight-tocomposite ratio is 75:25 wt.\%. At Universitas Syiah Kuala in Banda Aceh, Indonesia, TiO2/MMT composites were characterized using X-Ray Diffraction (XRD) by the Shimadzu Brand, Type: MAXima X XRD-7000. The molar ratio of methanol (Emsure) to palm oil (12: 1) was used to make biodiesel samples [7]. Transesterification is used in the processing of biodiesel. In a three-necked flask, palm oil and methanol are combined with 3 grams of $\mathrm{TiO}_{2} / \mathrm{MMT}$ composites, and the reflux process is carried out for 3 hours at the optimal reaction temperature of $60{ }^{\circ} \mathrm{C}$. At a speed of 250 rpm, the reflux mechanism was stirred. After 24 hours, this process produces two layers of liquid, namely biodiesel and glycerol, which are then separated. The percentage of biodiesel is measured using a GC-MS (Chromatography-Mass Spectrometry) system from Shimadzu (Type: QP2010 Plus) at Universitas Syiah Kuala in Banda Aceh, Indonesia. 


\section{RESULTS AND DISCUSSION}

The XRD strength plot for a $\mathrm{TiO}_{2} / \mathrm{MMT}$ composite sample as a function of $2 \theta$ is shown in Figure 1. According to XRF findings in previous studies, MMT (JCPDS 96-901-0958) includes $\mathrm{SiO}_{2}(\mathrm{Si}=25.04$ wt.\%, $\mathrm{O}=45.71$ wt.\%), which is more dominant than $\mathrm{Al}, \mathrm{Fe}, \mathrm{Ti}, \mathrm{Ca}, \mathrm{K}, \mathrm{S}$ [8]. This indicates that in MMT, low $\mathrm{SiO}_{2}$ crystals are more commonly associated with the quartz process (JCPDS 96-900-9667). Anatase process identifies $\mathrm{TiO}_{2}$ (JCPDS 96-710-3589). $\mathrm{TiO}_{2}$ crystals separate MMT peaks but do not result in the creation of a new step. $\mathrm{TiO}_{2}$ crystals peak at $2 \theta$, with values of $25.48,38.00,48.18$, 54.08, and 55.22. The $\mathrm{SiO}_{2}$ crystal has $2 \theta$ peaks, which are 20.86 and 26.64. This indicates that $\mathrm{TiO}_{2} / \mathrm{MMT}$ composites were successfully developed [13].

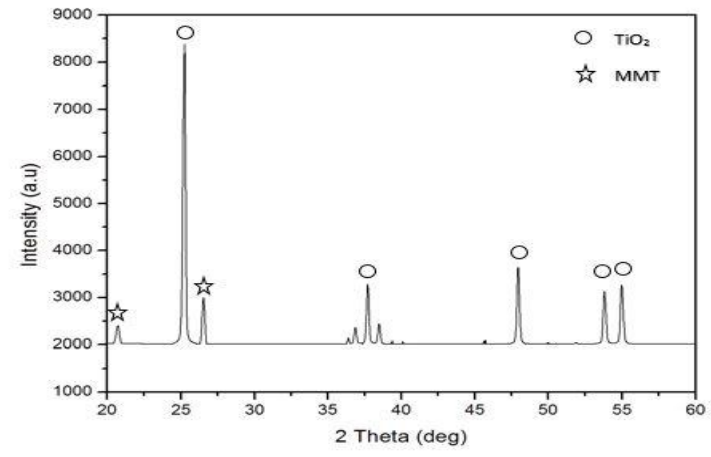

Fig. 1. XRD patterns of composite $\mathrm{TiO}_{2} / \mathrm{MMT}$.

The identification of FAME (Fatty Acid Methyl Ester) from the results of GC-MS research to produce biodiesel [14]. The goal is to figure out what the methyl ester building blocks are. Figure 2 and Table 1 display the percentage of the methyl ester component as a result of GC-MS analysis.

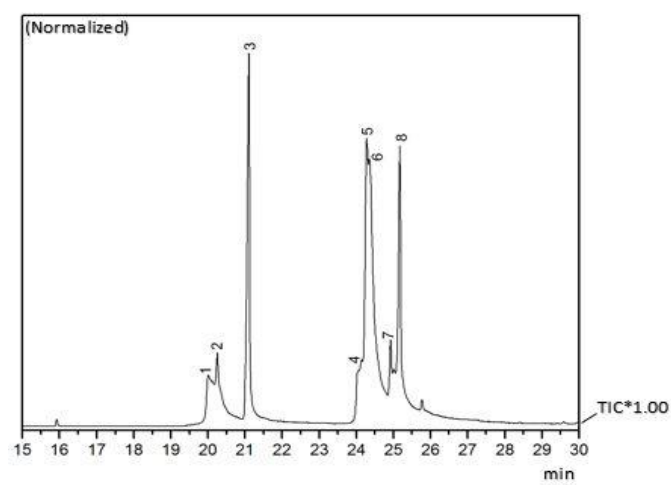

Fig. 2. GC-MS chromatogram of palm oil biodiesel product using $\mathrm{TiO}_{2} / \mathrm{MMT}$ composite catalyst.
TABLE I. IDENTIFICATION AND COMPOSITION OF BIODIESEL PRODUCTS

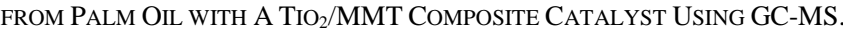

\begin{tabular}{|l|l|l|l|}
\hline Peak & \multicolumn{1}{|c|}{ Component } & Formula & \multicolumn{1}{|c|}{$\begin{array}{c}\text { Cmposition } \\
(\%)\end{array}$} \\
\hline 1 & Palmitic acid, methyl ester & $\mathrm{C}_{17} \mathrm{H}_{34} \mathrm{O}_{2}$ & 4.12 \\
2 & Palmitic acid, methyl ester & $\mathrm{C}_{17} \mathrm{H}_{34} \mathrm{O}_{2}$ & 7.34 \\
4 & $10, \quad$ 13-Octadecanoic acid, & $\mathrm{C}_{19} \mathrm{H}_{34} \mathrm{O}_{2}$ & 3.32 \\
5 & methyl ester & $\mathrm{C}_{19} \mathrm{H}_{36} \mathrm{O}_{2}$ & 17.16 \\
6 & Oleic acid methyl ester & $\mathrm{C}_{19} \mathrm{H}_{36} \mathrm{O}_{2}$ & 28.95 \\
& Oleic acid methyl ester & & \\
\hline
\end{tabular}

Peak 1 in the methyl ester has a material palmitic acid $\left(\mathrm{C}_{17} \mathrm{H}_{34} \mathrm{O}_{2}\right)$ with a retention time of 20.00 and a composition of $4.12 \%$, according to Figure 2 and Table 1. Peak 2 also contains palmitic acid, which has a retention time of 20.25 and a composition of $8.34 \%$. Peak 4 indicates a material called 10 , 13-Octadecanoic acid in ethyl ester $\left(\mathrm{C}_{19} \mathrm{H}_{34} \mathrm{O}_{2}\right)$ with a retention time of 24.15 and a $3.32 \%$ composition. Peak 5 with a retention period of 24.28 and composition of $17.16 \%$ suggests the presence of oleic acid $\left(\mathrm{C}_{19} \mathrm{H}_{36} \mathrm{O}_{2}\right)$ is the methyl ester. With a retention period of 24.35 and a composition of $28.95 \%$, it's also at a peak of 6 . Other acids that aren't in the methyl ester account for $39.10 \%$. Based on these findings in methyl ester, the total FAME obtained from palm oil by the transesterification method using a $\mathrm{TiO}_{2} / \mathrm{MMT}$ composite catalyst is $60.89 \%$. As an adsorbent, $\mathrm{SiO}_{2}$ in MMT absorbs water and is a source of impurities in biodiesel processing [15], so that glycerol separation between FAME will happen right away MMT made from natural bentonite cannot convert palm oil to biodiesel [7], but $\mathrm{TiO}_{2}$ metal oxide can improve transesterification catalyst activity [16]. This has been achieved to transform waste frying oil into biodiesel using a heterogeneous catalyst consisting of a mixture of metal oxides $\left(\mathrm{ZrO}_{2} / \mathrm{WO}_{3}\right)$ [16].

\section{CONCLUSION}

This study looked at MMT made from bentonite from Aceh Tamiang, Aceh, Indonesia, which was composited with $\mathrm{TiO}_{2}$ (75:25 wt.\%) for biodiesel production from palm oil. The separation of the crystalline peaks of $\mathrm{SiO}_{2}$ and $\mathrm{TiO}_{2}$ in $\mathrm{TiO}_{2} / \mathrm{MMT}$ composites was demonstrated by XRD results. There was no acid activation in $\mathrm{TiO}_{2} / \mathrm{MMT}$ composites, where $\mathrm{TiO}_{2}$ could increase catalyst activity. The percentage of biodiesel produced was $60.89 \%$ under ideal conditions, which included a reaction temperature of $65^{\circ} \mathrm{C}$, a reaction time of 3 hours, a molar ratio of methanol to palm oil of $12: 1$, and a $\mathrm{TiO}_{2} / \mathrm{MMT}$ composite catalyst loading of 3 grams. Based on these findings, $\mathrm{TiO}_{2} / \mathrm{MMT}$ composites from Aceh Tamiang bentonite, Aceh, Indonesia, can convert palm oil to biodiesel; however, they must be checked with various catalysts, metal oxide, and biodiesel feedstock loading variations.

\section{ACKNOWLEDGMENTS}

The author wishes to express his gratitude to LPPM Universitas Samudra for providing financial assistance to expand the internal study. The author earned funding through the Leading Basic Research (PDU) No. 554/UN54.6/PG/2020, which was awarded to him. 


\section{REFERENCES}

[1] A.M. Domingos, F.D. Pitt, and A.A. Chivanga Barros, "Purification of residual glycerol recovered from biodiesel production," South African J. Chem. Eng., vol. 29, no. 1, pp. 42-51, 2019.

[2] G. Sivaprakash et al., "Zinc based iron mixed oxide catalyst for biodiesel production from Entermorpha intestinalis, Caulerpa racemosa and Hypnea musicoformisis and antibiofilm analysis using leftover catalyst after transesterification," J. King Saud Univ., vol. 32, no. 2, pp. 1604-1611, 2020.

[3] K.Y. Wong, J.-H. Ng, C.T. Chong, S.S. Lam, and W.T. Chong, "Biodiesel process intensification through catalytic enhancement and emerging reactor designs: A critical review," Renew. Sustain. Energy Rev., vol. 116, p. 109399, 2019.

[4] V.C. Akubude, K.N. Nwaigwe, and E. Dintwa, "Production of biodiesel from microalgae via nanocatalyzed transesterification process: A review," Mater. Sci. Energy Technol., vol. 2, no. 2, pp. 216-225, 2019.

[5] M. Danish, T. Ahmad, M. Ayoub, B. Geremew, and S. Adeloju, "Conversion of flaxseed oil into biodiesel using KOH catalyst: Optimization and characterization dataset," Data Br., vol. 29, p. 105225, 2020.

[6] [I. Istadi, D.D. Anggoro, L. Buchori, D.A. Rahmawati, and D. Intaningrum, "Active acid catalyst of sulphated zinc oxide for transesterification of soybean oil with methanol to biodiesel," Procedia Environ. Sci., vol. 23, pp. 385-393, 2015.

[7] A.F.F. Farias et al., "Biodiesel obtained by ethylic transesterification using $\mathrm{CuO}, \mathrm{ZnO}$ and $\mathrm{CeO} 2$ supported on bentonite," Fuel, vol. 160, pp. 357-365, 2015.

[8] T. Harmawan, Y. Amri, and T.A. Fadlly, "Isolation and characterization montmorillonite nanoparticles of Aceh Tamiang bentonite as Patchouli oil (Pogostemon cablin) bleaching.," Orient. J. Chem., vol. 35, no. 5, pp. 1535-1538, 2019.
[9] K. Siregar, A. H. Tambunan, A. K. Irwanto, S. S. Wirawan, and T. Araki, "A comparison of life cycle assessment on Oil Palm (Elaeis guineensis Jacq.) and Physic Nut (Jatropha curcas Linn.) as feedstock for Biodiesel production in Indonesia," Energy Procedia, vol. 65, pp. 170-179, 2015.

[10] P. Muanruksa, J. Winterburn, and P. Kaewkannetra, “A novel process for biodiesel production from sludge palm oil," MethodsX, vol. 6, pp. 2838-2844, 2019.

[11] R.N.R. Sianipar, D. Ariyani, and I.F. Nata, "Conversion of palm oil sludge to biodiesel using alum and $\mathrm{KOH}$ as catalysts," Sustain. Environ. Res., vol. 27, no. 6, pp. 291-295, 2017.

[12] T.A. Fadly, N.A. Fauziyah, A. Rosyidy, Mashuri, and S. Pratapa, "Degradation activation energy determination of PEG 4000-quartz composites using dynamic mechanical analyzer (DMA) measurements," in AIP Conference Proceedings, 2017, vol. 1788, no. 1, p. 30033.

[13] R. Wati, T. A. Fadlly, and T. Harmawan, "Karakteristik Energi Gap (Eg) Komposit $\mathrm{ZnO} /$ Karbon Aktif Dari Tandan Sawit (Elaeis guineensis Jack)) untuk Aplikasi Sel Surya,” J. Fis., vol. 9, no. 2, pp. 60-68, 2019.

[14] M. Nurdin, F. Fatma, M. Natsir, and D. Wibowo, "Characterization of methyl ester compound of biodiesel from industrial liquid waste of crude palm oil processing," Anal. Chem. Res., vol. 12, pp. 1-9, 2017.

[15] A. Yulanda, L. Wahyuni, R. Safitri, A. Bakar, and M.D. Supardan, "Pemanfaatan Bentonit sebagai Penyerap Air pada Proses Transesterifikasi Minyak Jelantah Menjadi Biodiesel," J. Teknol. dan Ind. Pertan. Indones., vol. 10, no. 2, pp. 14-19, 2018.

[16] A.S. Yusuff and J.O. Owolabi, "Synthesis and characterization of alumina supported coconut chaff catalyst for biodiesel production from waste frying oil," South African J. Chem. Eng., vol. 30, pp. 42-49, 2019. 